\title{
Bacillus arenosi sp. nov., Bacillus arvi sp. nov. and Bacillus humi sp. nov., isolated from soil
}

\author{
Correspondence \\ Jeroen Heyrman \\ Jeroen.Heyrman@UGent.be
}

\author{
Jeroen Heyrman, ${ }^{1}$ Marina Rodríguez-Díaz, ${ }^{2}$ Joke Devos, ${ }^{1}$ Andreas Felske, ${ }^{3}$ \\ Niall A. Logan ${ }^{2}$ and Paul De Vos ${ }^{1}$ \\ ${ }^{1}$ Vakgroep BFM WE10V, Laboratorium voor Microbiologie, Universiteit Gent, K. L. \\ Ledeganckstraat 35, B-9000 Gent, Belgium \\ ${ }^{2}$ School of Biological and Biomedical Sciences, Glasgow Caledonian University, Cowcaddens \\ Road, Glasgow G4 OBA, UK \\ ${ }^{3}$ GBF (German Research Centre of Biotechnology), Division of Microbiology, Mascheroder Weg \\ 1, D-38124 Braunschweig, Germany
}

\begin{abstract}
A group of nine Gram-positive endospore-forming bacteria was isolated from soil of the Drentse A agricultural research area in the Netherlands. Using (GTG) 5 -PCR genomic fingerprinting and fatty acid analysis, the nine isolates were divided into three consistent groups. On the basis of $16 \mathrm{~S}$ rRNA gene sequence similarity of representative strains, the nine isolates were shown to belong to the genus Bacillus. The first group of four isolates was most closely related to Bacillus carboniphilus (95.5\%) and Bacillus sporothermodurans (95.5\%). The second and third groups of three and two isolates, respectively, showed highest sequence similarity to Bacillus neidei ( $97 \cdot 0$ and $97 \cdot 1 \%$, respectively) and Bacillus pycnus (both $96 \cdot 7 \%$ ). A DNA-DNA relatedness study confirmed the consistency of the three groups delineated by $(\mathrm{GTG})_{5}-\mathrm{PCR}$ and fatty acid analysis. A small number of phenotypic characters allowed differentiation of the three groups of isolates. The three groups therefore represent novel species, for which the names Bacillus humi, Bacillus arenosi and Bacillus arvi are proposed, with LMG $22167^{\top}$ (=DSM 16318 $)$, LMG 22166 ${ }^{\top}$ (=DSM 16319 $)$ and LMG $22165^{\top}$ $\left(=\mathrm{DSM} 16317^{\mathrm{T}}\right)$ as the respective type strains.
\end{abstract}

The genus Bacillus was first described by Cohn in 1872 and since then the number of Bacillus species has fluctuated widely among the eight editions of Bergey's Manual (Berkeley, 2002), ranging from a peak of 146 species in 1938 to a trough of 22 in 1974 (but with a further 26 appearing as species incertae sedis). The introduction of molecular methods, especially the use of 16S rRNA gene sequencing, has had a major impact on Bacillus taxonomy and has resulted in splitting of the genus. Ash et al. (1991), for example, studied the 16S rRNA gene sequences of 51 Bacillus species and revealed five phylogenetically distinct clusters of species and three ungrouped species. Three out of the five clusters and two out of the three ungrouped species have since been transferred to other genera

Published online ahead of print on 20 August 2004 as DOI 10.1099/ ijs.0.63240-0.

The GenBank/EMBL/DDBJ accession number for the 16S rRNA gene sequences of LMG 22165', LMG 22166 ${ }^{\top}$, LMG $22167^{\top}$ and LMG 22168 are AJ627211, AJ627212, AJ627210 and AJ627209, respectively.

The sporangial morphologies of B. arenosi and B. humi are provided as supplementary material in IJSEM Online.
(Wisotzkey et al., 1992; Ash et al., 1993; Shida et al., 1996; Nazina et al., 2001) and currently 59 species originally described as Bacillus have been transferred to related genera and Bacillus sensu stricto contains 99 species. Despite the reduction in the number of species in the genus Bacillus, the phylogenetic and physiological heterogeneity of what can now be considered as Bacillus sensu stricto is still far too large and the need for further splitting is supported by its widely ranging $\mathrm{G}+\mathrm{C}$ content, from 31 to $66 \mathrm{~mol} \%$.

The Drentse A agricultural research area, along the Anlooër Diepje brook near Anloo (the Netherlands), was the focus of a previous culture-independent study based on temperature-gradient gel electrophoresis (Felske \& Akkermans, 1998). This study revealed the presence of bacterial groups that predominated throughout the entire research area. Subsequent research (Felske et al., 1998) showed that hitherto-uncultured Bacillus species were the most active bacteria in these soils. Therefore, a large culturing campaign was undertaken using a multiplex PCR to screen specifically for novel Bacillus-related lineages in the soil (Felske et al., 2003). Positive isolates were analysed by their partial $16 \mathrm{~S}$ rRNA gene sequences to verify their taxonomic positions. Among the isolates, nine strains were present that, according 

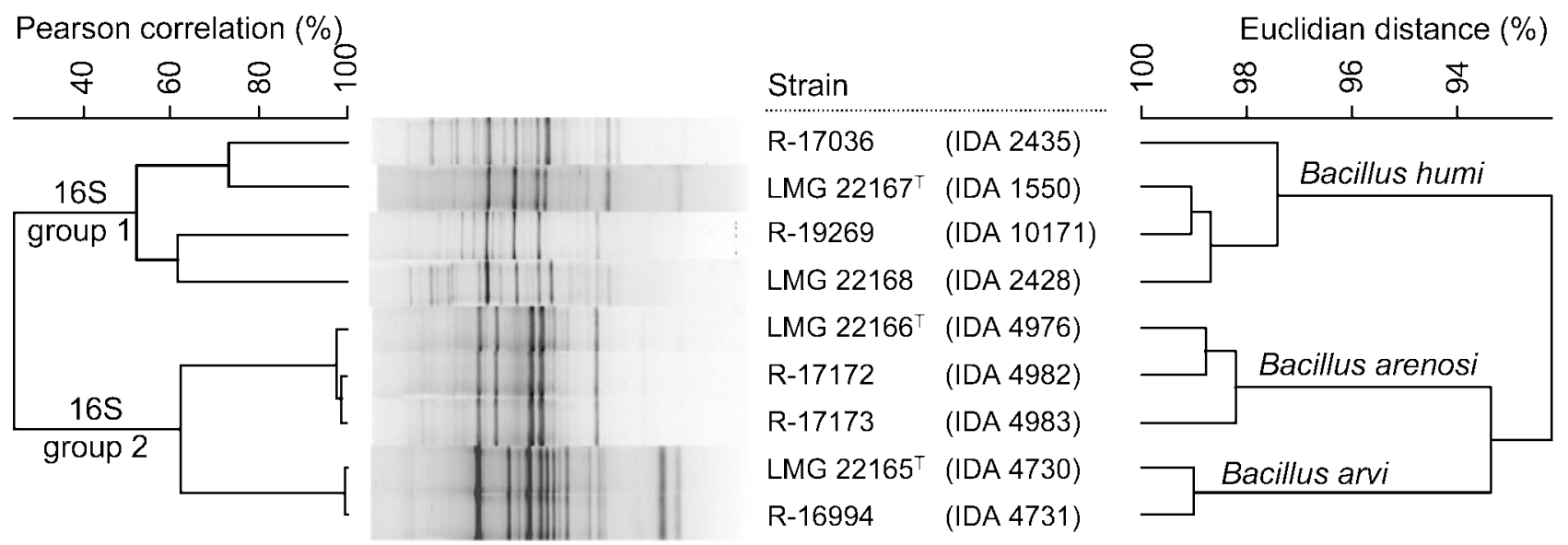

(a)

(b)

Fig. 1. Grouping based on normalized (GTG) $)_{5}-P C R$ patterns (a) and cellular fatty acid profiles (b) of the grassland isolates. Groups obtained by partial 16S rRNA gene sequencing as explained in the text are shown in (a) (16S rRNA groups 1 and 2). Novel species names are indicated in (b).

to partial $16 \mathrm{~S}$ rRNA gene sequencing, could represent at least two novel species; their strain numbers are given in Fig. 1. Sampling, enrichment, cultivation, high-throughput processing and screening with multiplex PCR were performed as described previously by Felske et al. (2003). Strains were subcultured further on nutrient agar (NA).

Purification of total genomic DNA for 16S rRNA gene sequencing and repetitive extragenic palindromic (rep)PCR fingerprinting was performed as described by Heyndrickx et al. (1996). Sequence analysis was performed as described previously by Heyrman \& Swings (2001). Phylogenetic trees were constructed using the BioNumerics software version 3.5 (Applied Maths) by applying the neighbour-joining and maximum-parsimony methods on a multiple-alignment similarity matrix. The stabilities of relationships were assessed by a bootstrap analysis of 1000 datasets. rep-PCR genomic fingerprinting was performed with the (GTG) 5 (microsatellite-specific) primer (Versalovic et al., 1994) applying PCR conditions described by Rademaker \& de Bruijn (1997). Electrophoresis and pattern analysis were performed as described by Heyrman et al. (2003). Analysis of the fatty acid content of the cell walls was performed as described previously (Heyrman et al., 1999), starting from cells grown on tryptic soy agar (TSA) for $48 \mathrm{~h}$.

On the basis of partial 16S rRNA gene sequencing targeting the first $\sim 500 \mathrm{bp}$ of the hypervariable region (Goto et al., 2000), the nine strains could be divided into two groups. The partial 16S rRNA gene sequences $(\sim 480 \mathrm{bp})$ of the strains attributed to the first group (LMG $22167^{\mathrm{T}}$, LMG 22168, R-17036 and R-19269) were highly similar, showing only three positions that contained a double reading in some of the strains and not in the others. In addition, the sequence of R-17036 had an insertion of an extra base not found in the other strains. Members of the second group of strains were also highly similar in their partial 16S rRNA gene sequences: strains LMG $22165^{\mathrm{T}}$ and R-16994 showed identical sequences and this was also the case for LMG $22166^{\mathrm{T}}$, R-17172 and R-17173. LMG $22165^{\mathrm{T}}$ and LMG $22166^{\mathrm{T}}$ showed only one base pair difference in the first $480 \mathrm{bp}$ of the $16 \mathrm{~S}$ rRNA gene. The partial sequence similarity between the two groups of strains was only $84-86 \%$.

To assess the variability among the grassland isolates further, they were investigated by $(\mathrm{GTG})_{5}$-PCR genomic fingerprinting (Fig. 1a) and fatty acid analysis (Fig. 1b). As expected, the two groups as revealed by 16S rRNA gene sequencing were also easily distinguishable by these two methods. Strains attributed to 16S rRNA group 1 showed quite variable (GTG) $)_{5}$ patterns and formed a coherent fatty acid group. In 16S rRNA group 2, strains with identical partial sequences also showed identical $(G T G)_{5}$ patterns and the one base pair difference between these two subgroups was reflected by a different pattern. In fatty acid analysis, the difference between the two subgroups was more pronounced: the mean percentages of the main fatty acid iso- $\mathrm{C}_{15: 0}$ were approximately 46 and $23 \%$ for the subgroups containing LMG $22166^{\mathrm{T}}$ and LMG $22165^{\mathrm{T}}$, respectively (Table 1 ). This led to the hypothesis that, despite their high partial $16 \mathrm{~S}$ rRNA gene sequence similarity, the two subgroups might represent two separate novel species. In a MIDI database search of the profiles generated for the grassland strains, the similarity with all existing Bacillus species included in the TSBA 4.0 database was below $50 \%$.

Based on the data obtained by (GTG) $)_{5}$-PCR and fatty acid analysis, representatives were selected for determination of their nearly complete $16 \mathrm{~S}$ rRNA gene sequences $(\sim 1500 \mathrm{bp})$, their DNA-DNA relatedness and their $\mathrm{G}+\mathrm{C}$ content 
Table 1. Comparison of mean fatty acid profiles of the three novel taxa and $B$. neidei and $B$. pycnus as measured by GC of fatty acid methyl esters

Data are mean percentages of total fatty acids \pm SD. Only fatty acids accounting for at least $1.0 \%$ of the total fatty acid content are listed. The summed feature comprises iso- $\mathrm{C}_{17: 1} \mathrm{I}$ and/or anteiso- $\mathrm{C}_{17: 1} \mathrm{~B}$. Data for B. neidei and B. pycnus are from Nakamura et al. (2002).

\begin{tabular}{|c|c|c|c|c|c|}
\hline Fatty acid & B. $\operatorname{arvi}(n=2)$ & B. arenosi $(n=3)$ & B. humi $(n=4)$ & B. neidei & B. pycnus \\
\hline iso- $\mathrm{C}_{14: 0}$ & $12 \cdot 8 \pm 0 \cdot 3$ & $5 \cdot 2 \pm 1 \cdot 7$ & $14 \cdot 9 \pm 2 \cdot 1$ & $5 \cdot 0$ & - \\
\hline $\mathrm{C}_{14: 0}$ & $1 \cdot 9 \pm 0 \cdot 1$ & $1 \cdot 8 \pm 0 \cdot 4$ & $<1 \cdot 0$ & - & - \\
\hline iso- $\mathrm{C}_{15: 0}$ & $23 \cdot 4 \pm 2 \cdot 1$ & $46 \cdot 2 \pm 3 \cdot 4$ & $33 \cdot 4 \pm 2 \cdot 7$ & $23 \cdot 6$ & $70 \cdot 3$ \\
\hline anteiso- $\mathrm{C}_{15: 0}$ & $16 \cdot 2 \pm 1 \cdot 1$ & $9 \cdot 8 \pm 1 \cdot 0$ & $38 \cdot 7 \pm 4 \cdot 7$ & $17 \cdot 8$ & $8 \cdot 1$ \\
\hline $\mathrm{C}_{15: 0}$ & $2 \cdot 2 \pm 0 \cdot 5$ & $3 \cdot 7 \pm 0 \cdot 9$ & $<1 \cdot 0$ & $1 \cdot 7$ & - \\
\hline $\mathrm{C}_{16: 1} \omega 7 c$ alcohol & $10 \cdot 7 \pm 1 \cdot 2$ & $4 \cdot 3 \pm 1 \cdot 2$ & $4 \cdot 1 \pm 0 \cdot 7$ & $4 \cdot 7$ & $6 \cdot 0$ \\
\hline iso- $\mathrm{C}_{16: 0}$ & $15 \cdot 1 \pm 1 \cdot 2$ & $5 \cdot 4 \pm 2 \cdot 1$ & $1 \cdot 8 \pm 1 \cdot 1$ & $8 \cdot 1$ & $3 \cdot 1$ \\
\hline $\mathrm{C}_{16: 1} \omega 11 c$ & $6 \cdot 1 \pm 0 \cdot 4$ & $7 \cdot 3 \pm 0 \cdot 8$ & $1 \cdot 8 \pm 0 \cdot 4$ & $14 \cdot 5$ & $1 \cdot 4$ \\
\hline $\mathrm{C}_{16: 0}$ & $1 \cdot 3 \pm 0 \cdot 0$ & $1 \cdot 5 \pm 0 \cdot 4$ & $<1 \cdot 0$ & $5 \cdot 4$ & - \\
\hline iso- $\mathrm{C}_{17: 1} \omega 10 c$ & $1 \cdot 3 \pm 0 \cdot 1$ & $4 \cdot 9 \pm 0 \cdot 1$ & $<1 \cdot 0$ & - & - \\
\hline Summed feature & $2 \cdot 4 \pm 0 \cdot 1$ & $2 \cdot 7 \pm 0 \cdot 2$ & $1 \cdot 0 \pm 0 \cdot 2$ & - & - \\
\hline iso- $\mathrm{C}_{17: 0}$ & $1 \cdot 9 \pm 0 \cdot 2$ & $3 \cdot 4 \pm 0 \cdot 5$ & $<1 \cdot 0$ & - & - \\
\hline anteiso- $\mathrm{C}_{17: 0}$ & $5 \cdot 0 \pm 0 \cdot 4$ & $3 \cdot 1 \pm 0 \cdot 1$ & $1 \cdot 4 \pm 0 \cdot 6$ & - & - \\
\hline
\end{tabular}

(mol\%). The selected strains were the two most divergent strains of $16 \mathrm{~S}$ rRNA group 1 (LMG $22167^{\mathrm{T}}$ and LMG 22168) and one strain from each subgroup of $16 \mathrm{~S}$ rRNA group 2 (LMG $22165^{\mathrm{T}}$ and LMG $22166^{\mathrm{T}}$ ). The nearly complete $16 \mathrm{~S}$ rRNA gene sequences of LMG $22167^{\mathrm{T}}$ and LMG 22168 only differed at one position (in the hypervariable region), which showed a $\mathrm{T}$ for the former and a double reading $(\mathrm{C}$ or $\mathrm{T})$ for the latter. The sequences of LMG $22165^{\mathrm{T}}$ and LMG $22166^{\mathrm{T}}$, each representing a subgroup of $16 \mathrm{~S}$ rRNA group 2, showed mismatches at three positions. For LMG $22167^{\mathrm{T}}$ and LMG 22168 (16S rRNA group 1), a FASTA search (Pearson \& Lipman, 1988) gave Bacillus carboniphilus and Bacillus endophyticus as the closest related established species (both $\sim 95.5 \%$ sequence similarity). The sequences of LMG $22165^{\mathrm{T}}$ and LMG $22166^{\mathrm{T}}$ (16S rRNA group 2) showed highest similarities to the type strains of Bacillus neidei ( $97 \cdot 1$ and $97 \cdot 0 \%$, respectively), Bacillus pycnus (both $96 \cdot 7 \%$ ) and Kurthia sibirica (both $96 \cdot 7 \%$ ). The close relatedness with Kurthia is not unexpected since this genus, and also the genus Caryophanon, clearly group within Bacillus in a dendrogram based on 16S rRNA gene sequences (Fig. 2). The strains of $16 \mathrm{~S}$ rRNA group 2 phylogenetically clustered together with $B$. neidei and formed endospores (although slow and scarce on rich media; see below), thereby supporting their attribution to the genus Bacillus. It is clear that the current taxonomic situation at the generic level can be criticized. From our data, a separate genus status for Kurthia, based on the absence of endospores (Keddie \& Shaw, 1986), does not coincide with the phylogenetic position of at least some of the taxa. However, whether species of Kurthia and Caryophanon should be transferred to the genus Bacillus, or vice versa, remains an open question. Farrow et al. (1994) performed a 16S rRNA gene-based phylogenetic study on bacilli containing cell walls based on lysine (group 2 bacilli of Ash et al., 1991) and several non-spore-forming genera including Kurthia, and concluded that phylogenetically the most consistent policy would be to exclude the Ash et al. group 2 bacilli (Bacillus sphaericus, Bacillus fusiformis, Bacillus insolitus, etc.) from the genus Bacillus. However, the Ash et al. group 2 bacilli are embedded in a larger cluster of Bacillus sensu stricto species and renaming of the group 2 bacilli would also result in a phylogenetically unsatisfactory taxonomic situation. Because additional data are needed to clarify the taxonomic

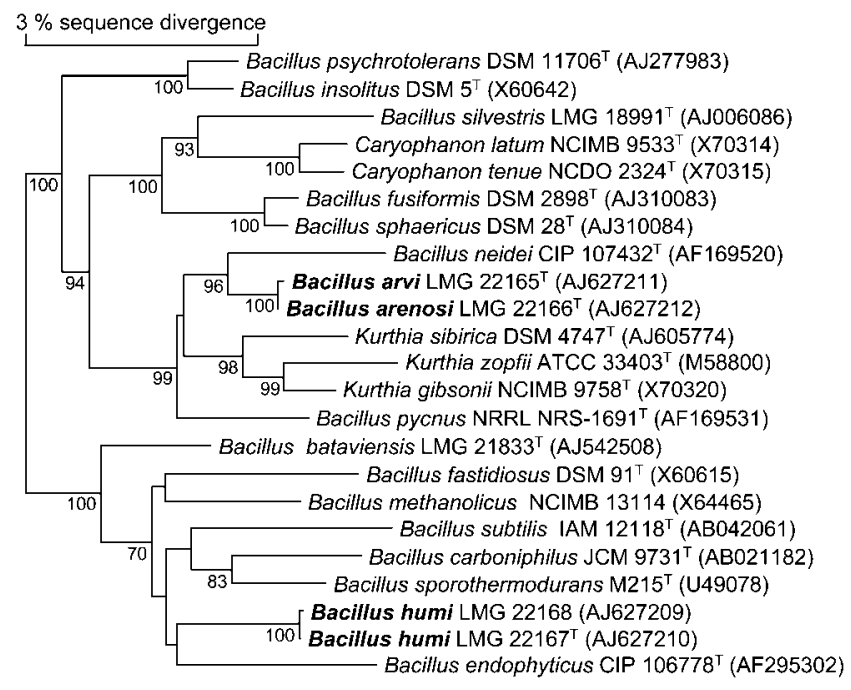

Fig. 2. Phylogenetic positions based on neighbour-joining of the 16S rRNA gene sequences of representative grassland isolates among related Bacillus species and members of the genera Kurthia and Caryophanon. Bootstrap values (expressed as percentages of 1000 replications) greater than $60 \%$ are shown at branch points. 
situation, the soil isolates studied here belonging to $16 \mathrm{~S}$ rRNA group 2 are best attributed to the genus Bacillus.

For determination of the G+C content and DNA-DNA hybridization, approximately $1 \mathrm{~g}$ biomass was harvested from agar plates and DNA was purified as described by Logan et al. (2000). DNA-DNA hybridization was performed using a modification of the microplate method described by Ezaki et al. (1989), as described by Willems et al. (2001). A hybridization temperature of $37^{\circ} \mathrm{C}$ was used. The $\mathrm{G}+\mathrm{C}$ content of DNA was determined by HPLC (Mesbah et al., 1989), using further specifications given by Logan et al. (2000). Generally recommended and accepted criteria for delineating bacterial species state that strains showing $3 \%$ or more $16 \mathrm{~S}$ rRNA gene sequence dissimilarity are considered to be representatives of separate species (Stackebrandt \& Goebel, 1994; Stackebrandt et al., 2002). Since the 16S rRNA gene sequence similarities of the grassland strains to all established species in the GenBank/ EMBL/DDBJ databases were around or just below this level, DNA-DNA hybridization experiments were only performed between representatives of the grassland isolates. The DNA-DNA relatedness value for LMG $22167^{\mathrm{T}}$ and LMG 22168, representative of $16 \mathrm{~S}$ rRNA group 1, was $87.0 \%$, indicating that $16 \mathrm{~S}$ rRNA group 1 represents a single novel Bacillus genomospecies, which will subsequently be referred to as Bacillus humi. The DNA-DNA relatedness between the representatives of the two subgroups of $16 \mathrm{~S}$ rRNA group 2 was $42.0 \%$. Therefore the strains of the two subgroups can be allocated to two novel genomospecies. Strains LMG $22165^{\mathrm{T}}$ and R-16994 are hereafter referred to as Bacillus arvi, and strains LMG $22166^{\mathrm{T}}, \mathrm{R}-17172$ and R-17173 as Bacillus arenosi.

The $\mathrm{G}+\mathrm{C}$ content of $B$. humi (determined for LMG $22167^{\mathrm{T}}$ and LMG 22168) was $37 \cdot 5 \mathrm{~mol} \%$. LMG $22165^{\mathrm{T}}$ (B. arvi) and LMG $22166^{\mathrm{T}}$ (B. arenosi) both had a G $+\mathrm{C}$ content of $35.0 \mathrm{~mol} \%$. For B. arvi and B. arenosi, the $\mathrm{G}+\mathrm{C}$ content was in the range of the related Bacillus species listed in Fig. 2 (34-41 \%; Claus \& Berkeley, 1986; Rheims et al., 1999; Abd El-Rahmanj et al., 2002; Nakamura et al., 2002) and of the genus Kurthia (36-38\%; Keddie \& Shaw, 1986; Belikova et al., 1986), but lower than the range given for Caryophanon (41-46\%; Trentini, 1986).

The strains were phenotypically characterized by the methods of Logan \& Berkeley (1984); other characters were determined and the data numerically analysed, as described by Logan et al. (2000). For observations on sporangia, cells were grown on NA supplemented with $5 \mathrm{mg} \mathrm{MnSO}_{4} \mathrm{l}^{-1}\left(\mathrm{NA} \mathrm{MnSO}_{4}\right)$ at $30^{\circ} \mathrm{C}$. Vegetative cells and sporangia were observed by phase-contrast microscopy. Strains were also examined for catalase and oxidase production and casein and starch hydrolysis using the methods of Gordon et al. (1973). Maximum and minimum growth temperatures were determined by incubating $10 \mathrm{ml}$ tryptic soy broth (TSB) cultures in a water bath; $\mathrm{pH}$ ranges for growth were determined using $10 \mathrm{ml}$ TSB cultures adjusted to $\mathrm{pH} 5 \cdot 0,7 \cdot 0$ and $9 \cdot 0$; both series were examined for turbidity at $24 \mathrm{~h}$ intervals. Growth under anaerobic conditions was tested in GasPak (BBL) jars. Strains were also tested for assimilation of substrates as sole carbon sources, using the API Biotype 100 kit as described by Heyndrickx et al. (1997).

In the phenotypic characterization tests, none of the strains was particularly reactive, and in the Biotype 100 substrate assimilation tests, none of the strains gave readable positive results. Consequently, although the three new species could be recognized and differentiated on the basis of routine tests, as the descriptions below make clear, the separation of the three species and their distinction from phenotypically similar organisms relied on relatively few features (Table 2). Spore formation of B. arvi and B. arenosi on NA $\mathrm{MnSO}_{4}$ was very slow and scarce: for some strains no spore formation could be recorded after 10 days of growth at $30{ }^{\circ} \mathrm{C}$ on this medium. Therefore, spore formation was tested further on a poor medium, half-strength Bacillus fumarioli agar ( $1 / 2 \mathrm{BFA}$; Logan et al., 2000) including $5 \mathrm{mg}$ $\mathrm{MnSO}_{4}$. On $1 / 2$ BFA spores were formed in both species after approximately 3 days incubation at $30^{\circ} \mathrm{C}$, and after 5 days vegetative cells could no longer be observed. The sporangial morphologies of $B$. arenosi and $B$. arvi are quite distinct from that of $B$. humi (Table 2; supplementary Figs A and B available in IJSEM Online). B. arvi, which was similar in fatty acid composition to B. neidei (Table 2), could be differentiated from the latter species by a positive urease reaction, slow and scarce endospore formation on NA, casein hydrolysis (weak) and anaerobic growth (weak).

\section{Description of Bacillus arenosi sp. nov.}

Bacillus arenosi (ar.en.o'si. L. gen. n. arenosi of a sandy place).

Cells are straight or slightly curved, round-ended, motile rods $(0 \cdot 8-1 \cdot 0 \times 3 \cdot 0-8 \cdot 0 \mu \mathrm{m})$ and occur singly and in pairs. Gram-stain reaction is variable amongst cells. Endospore formation is slow and scarce on $\mathrm{NA} \mathrm{MnSO}_{4}$ after 10 days incubation at $30^{\circ} \mathrm{C}$. On $1 / 2 \mathrm{BFA}$, endospores are formed abundantly after approximately 3 days incubation at $30^{\circ} \mathrm{C}$. Endospores are spherical and appear in terminal positions, swelling the sporangia slightly. After $24 \mathrm{~h}$ on NA at $30^{\circ} \mathrm{C}$, colonies are cream-coloured, semi-translucent and slightly raised, with irregular margins that may spread along the inoculation streak. They have glossy surfaces and their diameters are $1-2 \mathrm{~mm}$. Strict aerobes. They grow at 20 and $30{ }^{\circ} \mathrm{C}$ but are not able to grow at $45^{\circ} \mathrm{C}$. Strains grow at $\mathrm{pH} 9$ as profusely as at $\mathrm{pH} 7$, but are unable to grow at $\mathrm{pH}$ 5. Casein is not hydrolysed but biomass on casein agar produces a pale-pink, diffusible pigment. Starch is not hydrolysed. Strains tolerate 5 but not $7 \%(\mathrm{w} / \mathrm{v}) \mathrm{NaCl}$. Catalase-positive and oxidase-negative. In the API 20E strip, gelatin is weakly hydrolysed and nitrate is reduced, but reactions for $o$-nitrophenyl- $\beta$-D-galactoside (ONPG), arginine dihydrolase, lysine decarboxylase, ornithine decarboxylase, citrate utilization, hydrogen sulfide production, urease, indole production and Voges-Proskauer are 
Table 2. Characters that differentiate between B. arenosi, B. arvi, B. humi and phenotypically related species

+, $>85 \%$ Positive; $\mathrm{V}$, variable (26-74\% positive);,$- 0-15 \%$ positive; $\mathrm{W}$, weak positive reaction; ND, no data.

\begin{tabular}{|c|c|c|c|c|c|}
\hline Character & \multicolumn{3}{|c|}{ Grassland isolates } & \multicolumn{2}{|c|}{ Related species ${ }^{\star}$} \\
\hline Spore position & Terminal & Terminal & (Sub)Terminal & Terminal & Subterminal \\
\hline Swelling of sporangia & Slight & Slight & + & - & Slight \\
\hline Casein hydrolysis & $\mathrm{W}$ & - & No growth & - & - \\
\hline Pigment on casein agar & - & Pink & - & $\mathrm{v}$ & - \\
\hline Anaerobic growth & $\mathrm{W}$ & - & $\mathrm{W}$ & + & - \\
\hline Tolerance to $7 \% \mathrm{NaCl}$ & - & - & + & $\mathrm{V}$ & + \\
\hline ONPG & $\mathrm{W}$ & - & - & - & - \\
\hline$N$-Acetylglucosamine & $\mathrm{W}$ & - & - & $\mathrm{V}$ & $\mathrm{w}$ \\
\hline
\end{tabular}

${ }^{\star}$ B. neidei, B. pycnus and B. sphaericus are strict aerobes, form spherical spores in terminal, swollen sporangia, and do not produce urease. Casein hydrolysis is negative for B. neidei and B. pycnus and variable for B. sphaericus. The B. sporothermodurans type strain is totally unreactive in API $20 \mathrm{E} / 50 \mathrm{CH}$ tests and forms spherical to oval spores.

negative. In the API 50CHB gallery, acid is not produced from any of the carbohydrate substrates. In the Biotype 100 kit, no substrate is used as a single carbon source. The major cellular fatty acid is iso- $\mathrm{C}_{15: 0}$, present at approximately $46 \%$. The following fatty acids are present to at

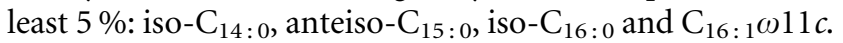

The $\mathrm{G}+\mathrm{C}$ content is $35.0 \mathrm{~mol} \%$ for the type strain, LMG $22166^{\mathrm{T}}\left(=\mathrm{DSM} 16319^{\mathrm{T}}\right)$. Isolated from soil (Drentse A agricultural research area, the Netherlands).

\section{Description of Bacillus arvi sp. nov.}

Bacillus arvi (ar'vi. L. gen. n. arvi of a field).

Cells are straight, round-ended, Gram-variable, motile rods $(0 \cdot 8-1 \cdot 0 \times 3 \cdot 0-8 \cdot 0 \mu \mathrm{m})$, occurring singly and in pairs. Endospore formation is slow and scarce on $\mathrm{NA} \mathrm{MnSO}_{4}$ after 10 days incubation at $30^{\circ} \mathrm{C}$. On $1 / 2 \mathrm{BFA}$, endospores are formed abundantly after approximately 3 days incubation at $30^{\circ} \mathrm{C}$. Endospores are spherical and appear in terminal positions, swelling the sporangia slightly. After $24 \mathrm{~h}$ on NA at $30^{\circ} \mathrm{C}$, colonies are butyrous, cream-coloured, semi-translucent and slightly raised, with irregular margins that may spread along the inoculation streak. They have granular textures and eggshell to glossy textured surfaces. Colony diameter is $1-3 \mathrm{~mm}$. Anaerobic growth occurs but is weak. Growth occurs at 20 and $30^{\circ} \mathrm{C}$ but not at $45^{\circ} \mathrm{C}$. Strains grow at $\mathrm{pH} 9$ as profusely as at $\mathrm{pH} 7$, but are unable to grow at $\mathrm{pH}$ 5. Casein is weakly hydrolysed. Starch is not hydrolysed. Strains tolerate $5 \%(\mathrm{w} / \mathrm{v}) \mathrm{NaCl}$ but not $7 \%$.
Catalase-positive and oxidase-negative. In the API 20E strip, the ONPG reaction is weakly positive and urease is produced. Arginine dihydrolase-, lysine decarboxylase- and ornithine decarboxylase-negative. Citrate is not utilized. Hydrogen sulfide and indole are not produced. The VogesProskauer reaction is negative and gelatin is not hydrolysed. Nitrate is not reduced to nitrite. In the API 50CHB, aesculin is not hydrolysed and acid without gas is produced from $\mathrm{D}$-fructose and weakly from $\mathrm{N}$-acetylglucosamine. No acid is produced from the other substrates. No substrate was used as the sole carbon source in the API Biotype 100 kit. The major cellular fatty acid is iso- $\mathrm{C}_{15: 0}$, present at approximately $23 \%$. The following fatty acids are present to at least 5\%: iso- $\mathrm{C}_{14: 0}$, anteiso- $\mathrm{C}_{15: 0}, \mathrm{C}_{16: 1} \omega 7 c$ alcohol, iso- $\mathrm{C}_{16: 0}, \mathrm{C}_{16: 1} \omega 11 \mathrm{c}$ and anteiso- $\mathrm{C}_{17: 0}$.

The $\mathrm{G}+\mathrm{C}$ content is $35.0 \mathrm{~mol} \%$ for the type strain, LMG $22165^{\mathrm{T}}\left(=\mathrm{DSM} 16317^{\mathrm{T}}\right)$. Isolated from soil (Drentse A agricultural research area, the Netherlands).

\section{Description of Bacillus humi sp. nov.}

Bacillus humi (hu'mi. L. gen. n. humi of earth, soil).

Cells are thin, slightly curved, round-ended, Gram-positive, highly motile rods $(0 \cdot 7-0 \cdot 9 \times 4 \cdot 0-7 \cdot 0 \mu \mathrm{m})$, occurring singly and in pairs. They produce ellipsoidal, sometimes spherical endospores that appear in subterminal or terminal positions and may swell the sporangia. After $24 \mathrm{~h}$ on NA at $30^{\circ} \mathrm{C}$, colonies are small (pin-head size, with diameters of approx. $1 \mathrm{~mm}$ ), convex, whitish and glossy, and the 
texture is watery. Growth occurs in anaerobic conditions but is weak. Optimum growth occurs at approximately $30{ }^{\circ} \mathrm{C}$; growth occurs at 20 but not at $45^{\circ} \mathrm{C}$. Strains grow at $\mathrm{pH} 9$ less profusely than at $\mathrm{pH} 7$ and no growth occurs at $\mathrm{pH}$ 5. Strains are unable to grow on skimmed-milk agar. Starch is not hydrolysed. Strains grow profusely in the presence of $7 \%(\mathrm{w} / \mathrm{v}) \mathrm{NaCl}$. Oxidase- and catalase-positive. In the API 20E strip, nitrate is reduced, but reactions for ONPG, arginine dihydrolase, lysine decarboxylase, ornithine decarboxylase, citrate utilization, hydrogen sulfide production, urease, indole production, Voges-Proskauer and gelatin hydrolysis are negative. In the API 50CHB, aesculin is hydrolysed and acid without gas is weakly and variably produced from arbutin, lactose and salicin. Acid production is negative for other carbohydrates. In the Biotype100 kit, aesculin and hydroxyquinoline- $\beta$ glucuronide are hydrolysed and the following substrates are used weakly as sole carbon sources: D-glucosamine, D-glucuronate and 2-keto-D-gluconate. The major cellular fatty acids are anteiso- $\mathrm{C}_{15: 0}$ and iso- $\mathrm{C}_{15: 0}$, present at approximately 39 and $33 \%$, respectively. The fatty acid iso- $\mathrm{C}_{14: 0}$ is present to at least $5 \%$.

The $\mathrm{G}+\mathrm{C}$ content is $37 \cdot 5 \mathrm{~mol} \%$ for the type strain, LMG $22167^{\mathrm{T}}\left(=\mathrm{DSM} 16318^{\mathrm{T}}\right)$. Isolated from soil (Drentse A agricultural research area, the Netherlands).

\section{Acknowledgements}

The authors acknowledge the financial support of the European Commission (grant EU-QLK3-2000-01678). J.D. and P.D.V. are grateful to the Fund for Scientific Research, Flanders, for research and personnel grants (contract G.0156.02). J.H. acknowledges Ghent University for his BOF-grant. We are most grateful to bioMérieux for providing API materials and for supporting M. R.-D.

\section{References}

Abd El-Rahmanj, H. A., Fritze, D., Spröer, C. \& Claus, D. (2002). Two novel psychrotolerant species, Bacillus psychrotolerans sp. nov. and Bacillus psychrodurans sp. nov., which contain ornithine in their cell walls. Int J Syst Evol Microbiol 52, 2127-2133.

Ash, C., Farrow, J. A. E., Wallbanks, S. \& Collins, M. D. (1991). Phylogenetic heterogeneity of the genus Bacillus revealed by comparative analysis of small-subunit-ribosomal RNA sequences. Lett Appl Microbiol 13, 202-206.

Ash, C., Priest, F. G. \& Collins, M. D. (1993). Molecular identification of rRNA group 3 bacilli (Ash, Farrow, Wallbanks, and Collins) using a PCR probe test. Proposal for the creation of a new genus Paenibacillus. Antonie van Leeuwenhoek 64, 253-260.

Belikova, V. A., Cherevach, N. V. \& Kalakutskii, L. V. (1986). A new species of bacteria of the genus Kurthia, Kurthia sibirica sp. nov. Mikrobiologiia 55, 831-835 (in Russian).

Berkeley, R. C. W. (2002). Whither Bacillus? In Applications and Systematics of Bacillus and Relatives, pp. 1-7. Edited by R. Berkeley, M. Heyndrickx, N. Logan \& P. De Vos. Oxford: Blackwell.

Claus, D. \& Berkeley, R. C. W. (1986). Genus Bacillus. In Bergey's Manual of Systematic Bacteriology, vol. 2, pp. 1105-1139. Edited by P. H. Sneath, N. Mair, M. E. Sharpe \& J. G. Holt. Baltimore: Williams \& Wilkins.
Cohn, F. (1872). Untersuchungen über Bakterien. Beitr Biol Pflanz 1, 127-244.

Ezaki, T., Hashimoto, Y. \& Yabuuchi, E. (1989). Fluorometric deoxyribonucleic acid-deoxyribonucleic acid hybridization in microdilution wells as an alternative to membrane filter hybridization in which radioisotopes are used to determine genetic relatedness among bacterial strains. Int J Syst Bacteriol 39, 224-229.

Farrow, J. A. E., Wallbanks, S. \& Collins, M. D. (1994). Phylogenetic interrelationships of round-spore-forming bacilli containing cell walls based on lysine and the non-spore-forming genera Caryophanon, Exiguobacterium, Kurthia, and Planococcus. Int J Syst Bacteriol 44, 74-82.

Felske, A. \& Akkermans, A. D. L. (1998). Spatial homogeneity of abundant bacterial 16S rRNA molecules in grassland soils. Microbiol Ecol 36, 31-36.

Felske, A., Wolterink, A., Van Lis, R. \& Akkermans, A. D. L. (1998). Phylogeny of the main bacterial 16S rRNA sequences in Drentse A grassland soils (The Netherlands). Appl Environ Microbiol 61, 871-879.

Felske, A., Heyrman, J., Balcaen, A. \& De Vos, P. (2003). Multiplex PCR screening of soil isolates for novel Bacillus-related lineages. J Microbiol Methods 55, 447-458.

Gordon, R. E., Haynes, W. C. \& Pang, C. H.-N. (1973). The Genus Bacillus. Agricultural Handbook no. 427. Washington, DC: USDA.

Goto, K., Omura, T., Hara, Y. \& Sadaie, Y. (2000). Application of the partial $16 \mathrm{~S}$ rDNA sequence as an index for rapid identification of species in the genus Bacillus. J Gen Appl Microbiol 46, 1-8.

Heyndrickx, M., Vauterin, L., Vandamme, P., Kersters, K. \& De Vos, P. (1996). Applicability of combined amplified ribosomal DNA restriction analysis (ARDRA) patterns in bacterial phylogeny and taxonomy. J Microbiol Methods 26, 247-259.

Heyndrickx, M., Lebbe, L., Vancanneyt, M. \& 7 other authors (1997). A polyphasic reassessment of the genus Aneurinibacillus, reclassification of Bacillus thermoaerophilus (Meier-Stauffer et al. 1996) as Aneurinibacillus thermoaerophilus comb. nov., and emended descriptions of $A$. aneurinilyticus corrig., A. migulanus, and A. thermoaerophilus. Int J Syst Bacteriol 47, 808-817.

Heyrman, J. \& Swings, J. (2001). 16S rDNA sequence analysis of bacterial isolates from biodeteriorated mural paintings in the Servilia tomb (necropolis of Carmona, Seville, Spain). Syst Appl Microbiol 24, $417-422$.

Heyrman, J., Mergaert, J., Denys, R. \& Swings, J. (1999). The use of fatty acid methyl ester analysis (FAME) for the identification of heterotrophic bacteria present on three mural paintings showing severe damage by microorganisms. FEMS Microbiol Lett 181, 55-62.

Heyrman, J., Logan, N. A., Busse, H.-J., Balcaen, A., Lebbe, L., Rodriguez-Diaz, M., Swings, J. \& De Vos, P. (2003). Virgibacillus carmonensis sp. nov., Virgibacillus necropolis sp. nov. and Virgibacillus picturae sp. nov., three novel species isolated from deteriorated mural paintings, transfer of the species of the genus Salibacillus to Virgibacillus, as Virgibacillus marismortui comb. nov. and Virgibacillus salexigens comb. nov., and emended description of the genus Virgibacillus. Int J Syst Evol Microbiol 53, 501-511.

Keddie, R. M. \& Shaw, S. (1986). Genus Kurthia. In Bergey's Manual of Systematic Bacteriology, vol. 2, pp. 1255-1258. Edited by P. H. Sneath, N. Mair, M. E. Sharpe \& J. G. Holt. Baltimore: Williams \& Wilkins.

Logan, N. A. \& Berkeley, R. C. W. (1984). Identification of Bacillus strains using the API system. J Gen Microbiol 130, 1871-1882.

Logan, N. A., Lebbe, L., Hoste, B. \& 7 other authors (2000). Aerobic endospore-forming bacteria from geothermal environments in northern Victoria Land, Antarctica, and Candlemas Island, South Sandwich archipelago, with the proposal of Bacillus fumarioli sp. nov. Int J Syst Evol Microbiol 50, 1741-1753. 
Mesbah, M., Premachandran, U. \& Whitman, W. B. (1989). Precise measurement of the $\mathrm{G}+\mathrm{C}$ content of deoxyribonucleic acid by high-performance liquid chromatography. Int J Syst Bacteriol 39, 159-167.

Nakamura, L. K., Shida, O., Takagi, H. \& Komagata, K. (2002). Bacillus pycnus sp. nov. and Bacillus neidei sp. nov., round-spored bacteria from soil. Int J Syst Evol Microbiol 52, 501-505.

Nazina, T. N., Tourova, T. P., Poltaraus, A. B. \& 8 other authors (2001). Taxonomic study of aerobic thermophilic bacilli: descriptions of Geobacillus subterraneus gen. nov., sp. nov. and Geobacillus uzenensis sp. nov. from petroleum reservoirs and transfer of Bacillus stearothermophilus, Bacillus thermocatenulatus, Bacillus thermoleovorans, Bacillus kaustophilus, Bacillus thermoglucosidasius and Bacillus thermodenitrificans to Geobacillus as the new combinations G. stearothermophilus, G. thermocatenulatus, G. thermoleovorans, G. kaustophilus, G. thermoglucosidasius and G. thermodenitrificans. Int J Syst Evol Microbiol 51, 433-446.

Pearson, W. R. \& Lipman, D. J. (1988). Improved tools for biological sequence comparison. Proc Natl Acad Sci U S A 85, 2444-2448.

Rademaker, J. L. W. \& De Bruijn, F. J. (1997). Characterization and classification of microbes by rep-PCR genomic fingerprinting and computer assisted pattern analysis. In DNA Markers: Protocols, Applications and Overviews, pp. 151-171. Edited by G. GaetanoAnollés \& P. M. Gresshoff. New York: Wiley.

Rheims, H., Frühling, A., Schumann, P., Rohde, M. \& Stackebrandt, E. (1999). Bacillus silvestris sp. nov., a new member of the genus Bacillus that contains lysine in its cell wall. Int J Syst Bacteriol 49, 795-802.
Shida, O., Takagi, H., Kadowaki, K. \& Komagata, K. (1996). Proposal of two new genera, Brevibacillus gen. nov. and Aneurinibacillus gen. nov. Int J Syst Bacteriol 46, 939-946.

Stackebrandt, E. \& Goebel, B. M. (1994). Taxonomic note: a place for DNA-DNA reassociation and $16 \mathrm{~S}$ rRNA sequence analysis in the present species definition in bacteriology. Int J Syst Bacteriol 44, 846-849.

Stackebrandt, E., Frederiksen, W., Garrity, G. M. \& 10 other authors (2002). Report of the ad hoc committee for the re-evaluation of the species definition in bacteriology. Int J Syst Evol Microbiol 52, 1043-1047.

Trentini, W. C. (1986). Genus Caryophanon. In Bergey's Manual of Systematic Bacteriology, vol. 2, pp. 1259-1260. Edited by P. H. Sneath, N. Mair, M. E. Sharpe \& J. G. Holt. Baltimore: Williams \& Wilkins.

Versalovic, J., Schneider, M., De Bruijn, F. J. \& Lupksi, J. R. (1994). Genomic fingerprinting of bacteria using repetitive sequence-based polymerase chain reaction. Methods Mol Cell Biol 5, 25-40.

Willems, A., Doignon-Bourcier, F., Goris, J., Coopman, R., de Lajudie, P., De Vos, P. \& Gillis, M. (2001). DNA-DNA hybridization study of Bradyrhizobium strains. Int $J$ Syst Evol Microbiol 51, 1315-1322.

Wisotzkey, J. D., Jurtshuk, P., Jr, Fox, G. E., Deinhard, G. \& Poralla, K. (1992). Comparative sequence analysis on the $16 \mathrm{~S}$ rRNA (rDNA) of Bacillus acidocaldarius, Bacillus acidoterrestris, and Bacillus cycloheptanicus and proposal for creation of a new genus, Alicyclobacillus gen. nov. Int J Syst Bacteriol 42, 263-269. 